Al-Mashrafiyah: Jurnal Ekonomi, Keuangan dan Perbankan Syariah

ISSN (p): 2597-4904 ISSN (e) : 2620-5661

Volume 4 , Nomor 2 , Oktober (2020), h. 57-68

https://doi.org/10.24252/al-mashrafiyah.v4i2.15439

\title{
RISIKO PEMBIAYAAN PADA BANK SYARIAH DI INDONESIA: TINJAUAN ATAS PEMBIAYAAN BERBASIS BAGI HASIL
}

\author{
Purwanto $^{1}$, M. Kevin Ramadani ${ }^{2}$ dan Yeny Fitriyani ${ }^{3}$ \\ Program Studi Ekonomi Syariah, STAI Al Husain ${ }^{1,2,3}$ \\ purwanto@staia-sw.ac.id ${ }^{1}$,kevinramadani21@gmail.com², yenyfit@staia-sw.ac.id³ \\ Received: 21-8-2020; Revised: 02-10-2020; Accepted; 22-10-2020
}

\begin{tabular}{ll}
\hline Keywords: & \multicolumn{1}{c}{ ABSTRACT } \\
\cline { 2 - 3 } Profit Sharing & This study aims to analyze the contribution of risk-based financing. The financing risk in this study \\
Financing, Sharia & is measured by non-performance financing . The type of study used is quantitative research with an \\
Commercial Bank, & explanatory approach. The type of data used is secondary data collected by the documentation method. \\
NPF & Data analysis using panel data regression analysis. Based on the results of studies that have been \\
& carried out, the report taken in this study is profit-sharing financing which has an influence on the risk \\
& of financing in Islamic banks in Indonesia. These results indicate that increased financing is based on \\
& principles that can reduce the risk of problems. From the results of the study, it is important for Islamic \\
& banking banks to take the right policy regarding the distribution of financing with the principle of \\
& profit-sharing (mudharabah and musyarakab). In financing with the profit-sharing principle that has \\
& a bigh risk, however, the criteria for syariah commercial banks to comply with the requirements set by \\
& the Financial Services Authority can prevent problematic risks.
\end{tabular}

Kata Kunci:

ABSTRAK

Penelitian ini bertujuan untuk menganalisis bagaimana kontribusi pembiayaan Pembiayaan Bagi berbasis bagi hasil terhadap risiko pembiayaan. Risiko pembiayaan dalam Hasil, Bank penelitian ini dikukur dengan non performance financing (NPF). Jenis studi yang Umum Syariah, digunakan adalah penelitian kuantitatif dengan pendekatan eksplanatori. Jenis $\mathrm{NPF}$ data yang digunakan adalah data sekunder yang dikumpulkan dengan metode dokumentasi. Analisis data menggunakan analisis regresi data panel. Berdasarkan hasil studi yang telah dilakukan maka kesimpulan yang dapat diambil dalam studi ini adalah pembiayaan bagi hasil memiliki pengaruh negatif terhadap risiko pembiayaan pada bank syariah di Indonesia. Hasil ini menunjukakan bahwa peningkatan pembiayaan dengan prinsip bagi hasil dapat mengurangi risiko pembiayaan bermasalah atau NPF . Dari hasil studi ini maka penting bank pelaku perbankan syariah untuk mengambil kebijakan yang tepat mengenai penyaluran pembiayaan dengan prinsip bagi hasil (mudharabah dan musyarakah). Pada dasarnya pembiayaan dengan prinsip bagi hasil memiliki risiko yang tinggi, namun apabila bank umum syaraiah mematuhi persyaratan standar yang ditetapkan oleh Otoritas Jasa Keuangan maka risiko pembiayaan bermasalah dapat dicegah. 


\section{PENDAHULUAN}

Laporan Global Islamic Finance Report (GIFR) menempatkan Indonesia sebagai negara dengan Pasar Keuangan Syariah Global tertinggi didunia (Santoso \& Nurzaman, 2020). Tingginya pasar keuangan syariah global di Indonesia tidak terlepas dari besarnya jumlah penduduk muslim di Indonesia. Dengan demikian kehadiran industri keuangan syariah menjadi salah pilihan masyarakat muslim dalam memanfaatkan jasa keuangan (Purwanto, 2019a). Salah satu industri keuangan syariah yang ada di Indonesia adalah industri pada sektor perbankan syariah.

Sejak undang-undang No 21 Tahun 2008 tentang perbankan syariah di sahkan, industri perbankan syaraiah terus mengalami perkembangan signifikan (Purwanto, 2018). Perkembangan tersebut dapat dilihat dari jumlah entitas bisnis seperti perbankan syariah baik berupa bank umum syariah, unit usaha syariah dan Bank Pembiayaan Rakyat syariah. Hingga tahun 2019 jumlah entitas bank umum syariah mencapai 480 jaringan kantor, Unit Usaha Syariah memiliki jumlah jaringan kantor sebanyak 161 dan jumlah jaringan bank Bank Pembiayaan Rakyat syariah mencapai 170 (OJK, 2020). Selain jumlah entitas, perkembangan perbankan syariah juga dapat dilihat dari pertumbuhan aset, pertumbuhan pembiayaan yang diberikan (PYD) dan pertumbuhan dana pihak ketiga (DPK). Dalam kurun waktu tahun 2015 sampai dengan Juni 2019 pertumbuhan Aset, PYD dan DPK mengalami pertumbuhan yang fluktuatif, data selengkapnya dapat dilihat pada gambar 1 berikut:

\section{Gambar 1: Perkembangan Bank Syariah di Indonesia}

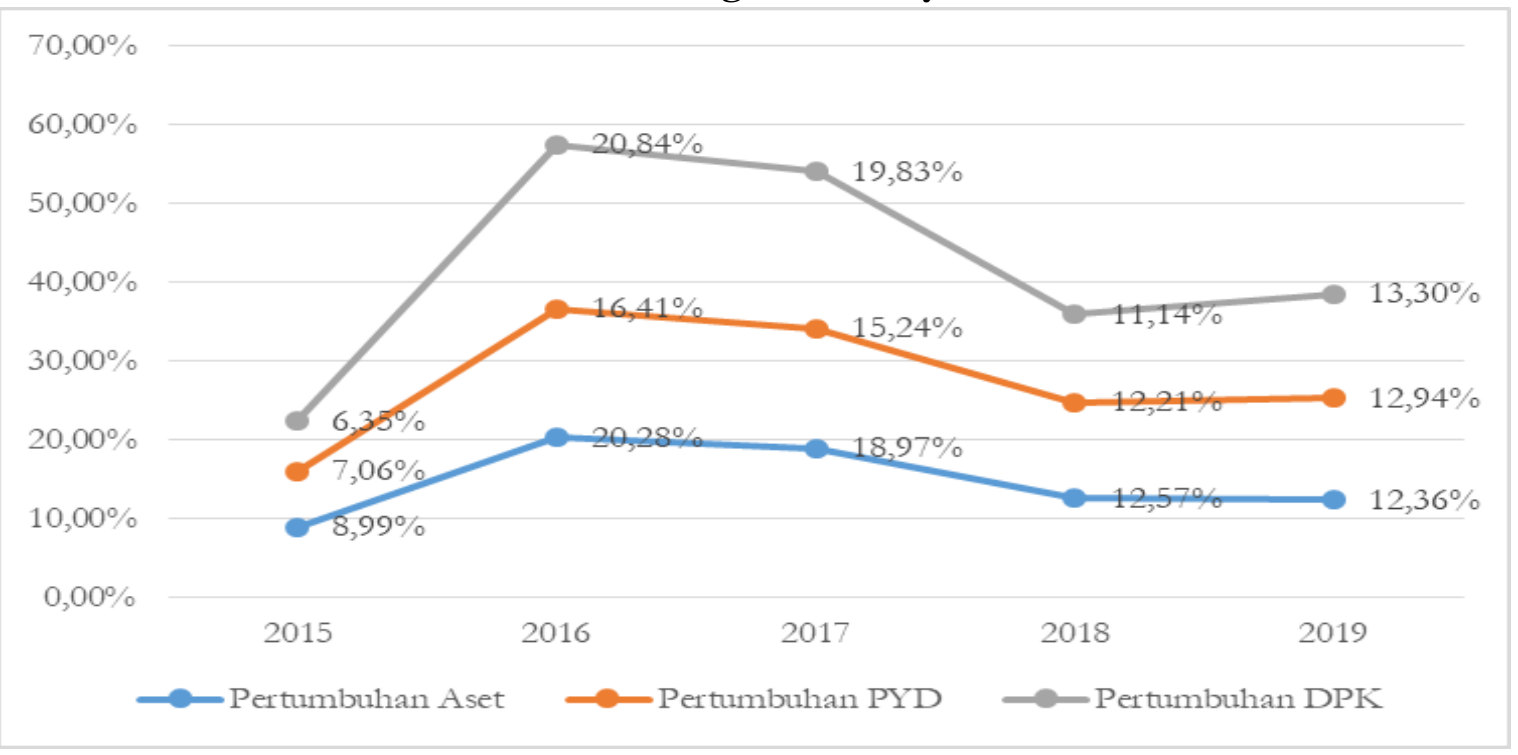

Sumber: OJK, 2019

Dari gambar di atas menunjukkan bahwa perbankan syariah berhasil menunjukkan perkembangan dan eksistensinya dalam industri keuangan di Indonesia (Purwanto, 2019a). Sebagaimana lembaga bisnis, entitas bisnis perbankan syariah juga mengharapkan laba atau keuntungan. Hal ini dikarenakan salah satu tujuan dari lembaga bisnis adalah untuk mendapatkan keuntungan atau laba (Abraham \& Harrington, 2013). Laba perbankan syariah tentu saja diperoleh melalui aktivitas bisnisnya salah satunya melalui penyaluran pembiayaan. Dengan demikian perbankan syariah harus mampu menyalurkan pembiayaan pada sektor dan akad yang tepat. Pembiayaan merupakan aktivitas yang dilakukan perbankan syariah dalam memberikan sejumlah dana untuk kegiatan bisnis (Purwanto, 2019b). Dengan kata lain pembiayaan yang disalurkan oleh bank syariah pada dasarnya untuk kegiatan produktif.

Dalam penyaluran pembiayaan, salah satu prinsip yang diterapkan adalah prinsip bagi hasil (Wangsawidjaja, 2012). Lebih lanjut prinsip bagi hasil diimplementasikan dengan akad mudharabah dan musyarakah. Kendati pembiayaan dengan prinsip bagi basil dinilai memiliki risiko yang tinggi 
(Afzal \& Hassan, 2018; Sutrisno, 2015; Warninda, Ekaputra, \& Rokhim, 2019), namun pada kenyataannya pembiayaan dengan prinsip bagi hasil, dalam kurun waktu empat tahun terakhir ternyata selalu mengalami peningkatan. Data selengkapnya dapat dilihat pada gambar 2 berikut:

\section{Gambar 2: Perkembangan Penyaluran Pembiayaan dengan Prinsip Bagi Hasil}

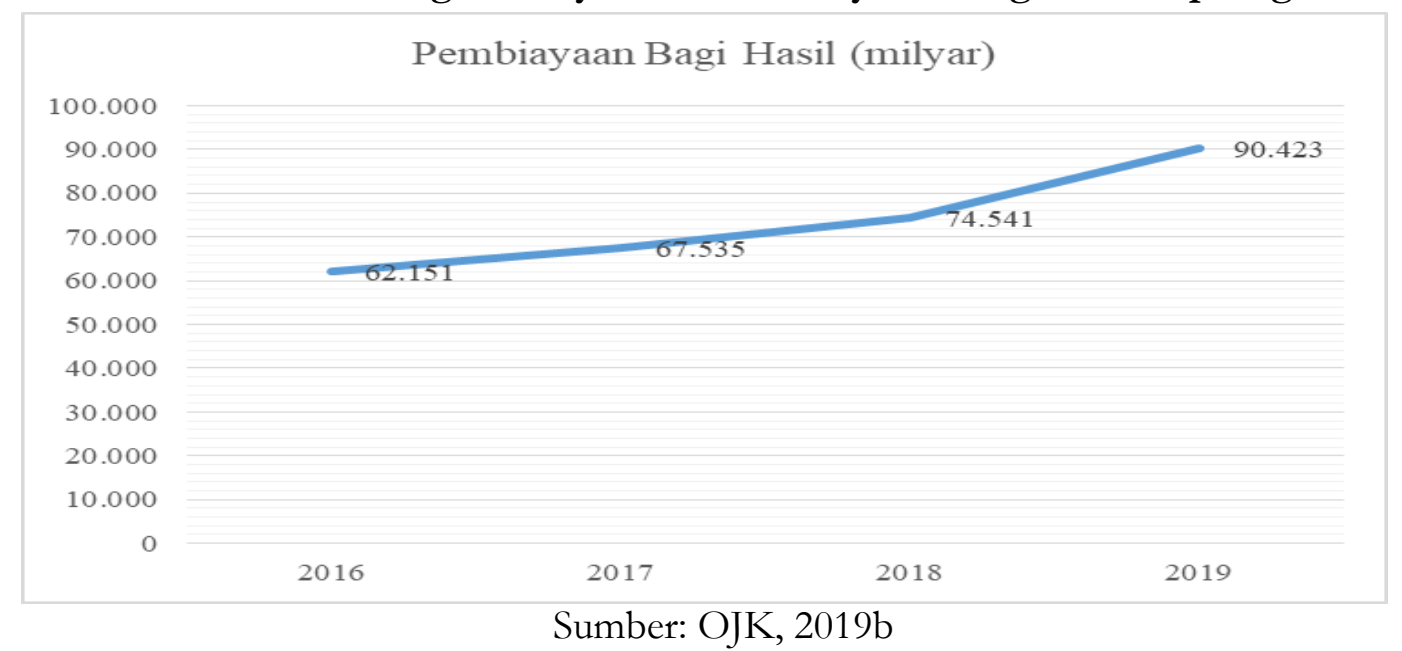

Gambar 2 diatas menunjukkan bahwa pembiayaan dengan prinsip bagi hasil pada perbankan syariah selalu mengalami peningkatan. Padahal pembiayaan dengan prinsip bagi hasil memiliki risiko yang lebih tinggi bila dibandingkan dengan prinsip pembiayaan lainnya (Hadi, 2011; Sutrisno, 2015; Warninda et al., 2019). Risiko pembiayaan pada lembaga keuangan syariah salah satunya ditentukan dengan rasio Non performing Financing atau pembiayaan bermasalah (Koju, Koju, \& Wang, 2018). NPF harus dihindari oleh perbankan syariah karena berdampak pada berkurangnya keuntungan (Belkhaoui, Alsagr, \& van Hemmen, 2020) dan bahkan dapat mengurangi aset. Sehingga NPF yang tinggi dapat menyebabkan lembaga keuangan tidak memiliki kesempatan untuk mendapatkan keuntungan (Asfaw, Bogale, \& Teame, 2016).

Tingginya risiko dalam pembiayaan dengan prinsip bagi hasil dibuktikan oleh beberapa studi, seperti studi yang dilakukan oleh Putra (2019) yang membuktikan bahwa pembiayaan mudharabah berdampak positif terhadap pembiayaan bermasalah. Artinya pembiayaan dengan akad mudharabah berpotensi meningkatkan jumlah pembiayaan bermasalah. Sementara studi yang dilakukan oleh Warninda et al., (2019) juga membuktikan bahwa pembiayaan dengan akad musyarakah memiliki risiko, karena berpengaruh positif terhadap pembiayaan bermasalah (Aprilianto, 2020). Demikian halnya dengan studi yang dilakukan oleh Afzal \& Hassan (2018) yang juga menunjukkan bahwa faktor risiko adalah salah satu penghambat minimnya penerapan akad mudharabah dalam pembiayaan bank syariah di Pakistan. Studi yang dilakukan oleh Husa \& Trinarningsih (2015) yang membuktikan bahwa risiko pembiayaan pada bank syariah lebih tinggi bila dibandingkan dengan risiko pembiayaan pada bank konvensional. Kondisi ini menunjukkan bahwa pembiayaan dengan prinsip bagi hasil adalah pembiayaan yang memiliki risiko dan dapat menyebabkan meningkatnya pembiayaan bermasalah.

Uraian di atas menunjukkan bahwa pembiayaan dengan prinsip bagi hasil, sebagaimana dibuktikan oleh hasil-hasil studi yang telah dilakukan menunjukkan adanya risiko pembiayaan yang tinggi. Kendati memiliki risiko pembiayaan yang tinggi, namun pembiayaan dengan prinsip bagi hasil sebenarnya memiliki imbal bagi hasil (Ernawati, 2016). Artinya keuntungan yang diperoleh oleh perbankan syariah akan lebih tinggi jika menerapkan pembiayaan dengan prinsip bagi hasil. Kondisi inilah kemungkinan yang menjadi faktor mengapa pembiayaan dengan prinsip bagi hasil selalu mengalami peningkatan di Indonesia. Bahkan studi yang dilakukan oleh Putri, Yuliana, \& Yulianita (2018) membuktikan bahwa berbasis bagi hasil dengan akad mudharabah berpengaruh negatif terhadap pembiayaan bermasalah. Artinya pembiayaan dengan prinsip bagi hasil seperti mudharabah justru dapat mengurangi risiko pembiayaan. Demikian halnya studi yang dilakukan 
oleh Adzimatinur \& Manalu (2020) membuktikan bahwa pembiayaan bagi hasil dengan akad musyarakah memiliki pengaruh negatif dan signifikan terhadap pembiayaan bermasalah.

Dari uraian di atas menunjukkan bahwa ada permasalahan menarik yang perlu ditelusuri mengenai pembiayaan bermasalah berdasarkan pembiayaan bagi hasil. Studi lain membuktikan bahwa pembiayaan bagi hasil memiliki risiko yang tinggi, sehingga perbankan syariah enggan menggunakannya. Namun data menunjukkan bahwa pembiayaan bagi hasil oleh perbankan syariah justru mengalami peningkatan. Berdasarkan kondisi inilah studi ini dilakukan guna membuktikan bagaimana kontribusi pembiayaan bagi hasil terhadap risiko pembiayaan pada bank syariah di Indonesia.

\section{LANDASAN TEORI}

Secara garis besar ada empat prinsip yang dapat digunakan oleh bank syariah dalam menyalurkan pembiayaan, salah satunya adalah prinsip bagi hasil (Purwanto dan Yanuar, 2017). Pembiayaan dengan prinsip bagi hasil yang umum digunakan oleh bank syariah adalah akad mudharabah dan akad musyarakat (Ahmadiono, 2013). Akar kata mudharabah berasal dari dharb, yang memiliki arti memukul. Memukul memiliki makna proses seseorang yang memukulkan kakinya dalam menjalankan bisnisnya(Al-Hasani, 2017). Secara istilah mudharabah menurut Antonio (2009) adalah akad kerjasama antara dua pihak dimana salah satu pihak bertindak sebagai shabibul maal yang menyediakan dana 100\%, sedangkan pihak yang lain bertindak menjadi mudharib pengelola dana. Dengan demikian pembiayaan mudharabah pada dasarnya adalah mekanisme pembiayaan dimana bank memberikan sejumlah dana kepada pengelola proyek (nasabah) dengan keuntungan dan risiko (Karim, 2010) akan didistribusikan ke bank dan nasabah sesuai nisbah bagi hasil yang telah disepakati (Sutrisno, 2016). Kata kunci dalam akad mudharabah adalah pihak bank berperan sebagai penyedia dana, sedangkan nasabah berperan sebagai pengelola. Skema dalam pembiayaan mudharabah dapat dilihat pada gambar 3 berikut

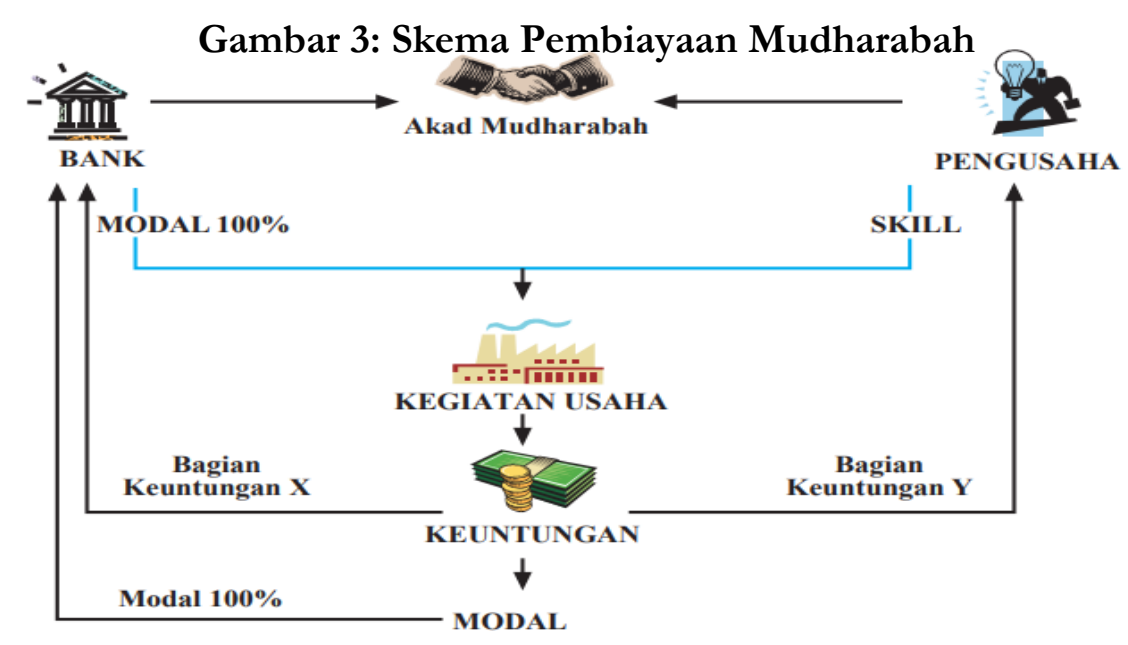

Sumber: Ascarya \& Yumanita (2005)

Adapun pembiayaan musyarakah atau sering disebut syarikah atau syirkah berarti sekutu, atau teman peseroan, perkumpulan, perserikatan. Syirkah secara etimologis berarti campur atau percampuran. Percampuran berarti seseorang mencampurkan hartanya dengan harta orang lain sehingga untuk membedakan harta antara yang satu dengan lainnya sulit untuk dibedakan (Sa'diyah \& Aziroh, 2014). Dalam dunia perbankan musyarakah adalah mekanisme pembiayaan dimana bank dan nasabah sama-sama berkontribusi atas sejumlah modal atau dana pada suatu proyek tertentu dengan keuntungan dan risko menjadi ditanggungjawab bersama sesuai dengan kesepakatan (Sutrisno, 2016). Dengan demikian kata kunci dalam akad musyarakah adalah kedua belah pihak saling berkontribusi terhadap modal. Artinya semua pihak, dalam hal ini pihak perbankan syariah ataupun pihak pengelola bisnis (nasabah), keduanya berkontribusi terhadap modal yang digunakan 
dalam penyelesaikan suatu proyek. Skema dalam pembiayaan musyarakah dapat dilihat pada gambar 4 berikut

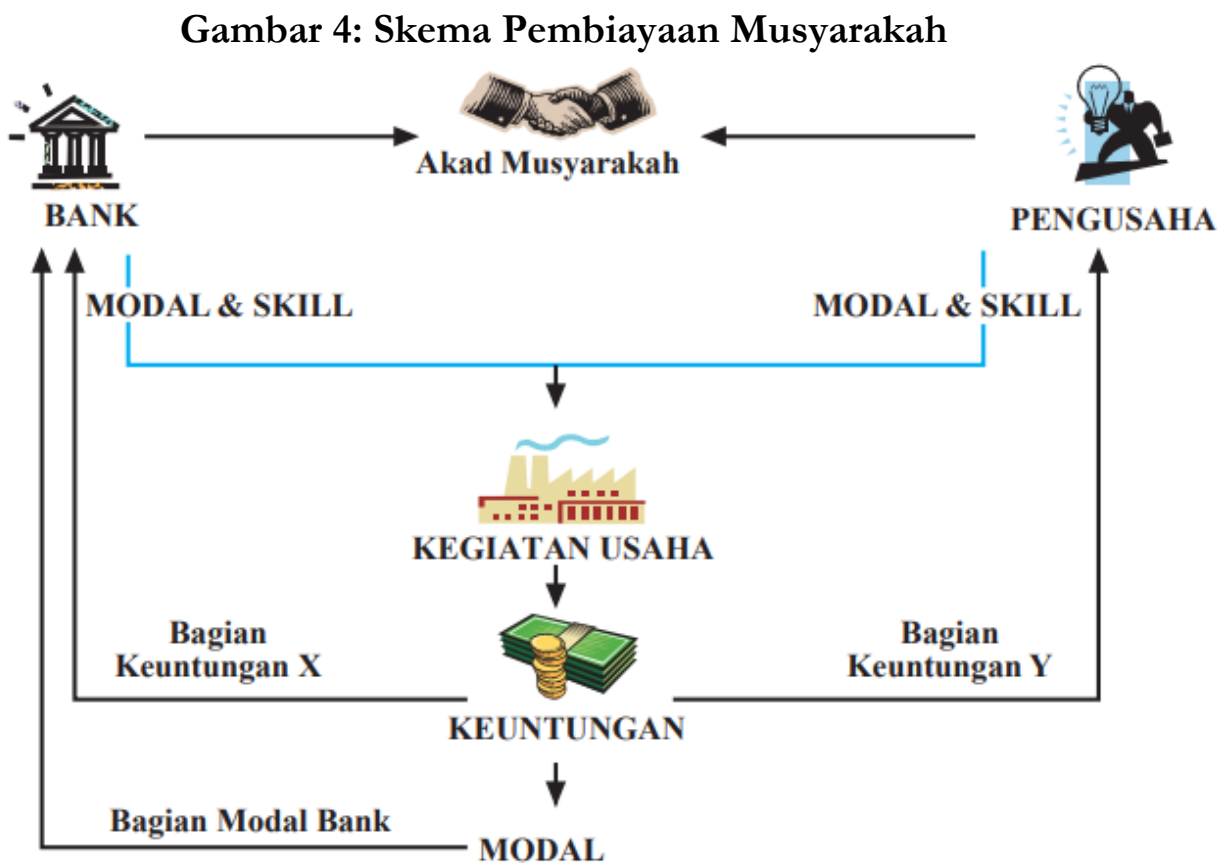

Sumber: Ascarya \& Yumanita (2005)

Secara garis besar ada perbedaan dari kedua skema pembiayaan tersebut dapat dijelaskan pada tabel berikut:

Tabel 1: Perbedaan Akad Mudharabah dan Akad Musyarakah

\begin{tabular}{|c|c|c|}
\hline Aspek & Mudharabah & Musyarakah \\
\hline Sumber Investasi & Pemilik Modal (Shohibul Maal) & Semua mitra usaha \\
\hline Partisipasi Manajemen & Pengelola (Mudharib) & Semua mitra usaha \\
\hline Pembagian Risiko & Pemilik Modal (Shohibul Maal) & $\begin{array}{l}\text { Semua mitra usaha sebatas } \\
\text { bagian investasinya }\end{array}$ \\
\hline $\begin{array}{l}\text { Kewajiban } \quad \text { Pemilik } \\
\text { Modal }\end{array}$ & Sebatas Modal & $\begin{array}{l}\text { Tidak terbatas atau sebatas } \\
\text { modal }\end{array}$ \\
\hline Status Kepemilikan Aset & $\begin{array}{l}\text { Milik Pemilik Modal (Shohibul } \\
\text { Maal) }\end{array}$ & $\begin{array}{l}\text { Milik bersama semua mitra } \\
\text { usaha }\end{array}$ \\
\hline Bentuk Penyertaan & Dana & Dana dan barang investasi \\
\hline
\end{tabular}

Sumber: Ascarya \& Yumanita, 2005

Pada pelaksanaan pembiayaan dengan prinsip bagi hasil, bank syariah pada dasarnya berperan sebagai pemilik modal yang membedakan adalah porsi modal. Jika pada akad mudharabah 100\% modal dari bank syariah, namun pada akad musyarakah bank syariah juga berperan sebagai pemilik modal namun hanya sebagian. Sebagai pemilik modal maka bank syariah berkepentingan untuk menjaga agar modal yang ditanamkan mendatangkan keuntungan. Namun dalam pelaksanaannya bank syariah ataupun nasabah tidak bisa menjamin bahwa usaha yang dijalankan selalu mendapatkan untung, sehingga dalam proses penyaluran pembiayaan dengan prinsip bagi hasil, Otoritas Jasa Keuangan telah menyiapkan sejumlah standar yang harus dipatuhi.

Dalam pembiayaan dengan akad mudharabah syarat yang harus dipenuhi Syarat standar tersebut seperti minimal usaha telah berjalan 2 tahun untuk nasabah $W$ alk in Client. Bagi nasabah yang mendapatkan rekomendasi dari nasabah eksisting serta memiliki manajemen yang baik dapat memperoleh pembiayaan mudharabah apabila telah menjalankan usahanya minimal 1 tahu. Syarat standar selanjutnya adalah nasabah memiliki kolektibilitas minimum lancar selama 6 bulan berturut- 
turut (OJK, 2017). Sementara pada pembiayaan musyarakah syarat yang harus dipenuhi seperti usaha dijalankan oleh badan usaha yang telah memenuhi syarat terkait dokumen perijinan yang diperlukan seperti Akta Perusahaan, Nomor Pokok Wajib Pajak serta kelengkapan dokumendokumen perijinan usaha. Syarat standar lainnya adalah nasabah perorangan maupun Badan Usaha tidak tercantum dalam daftar hitam dan daftar kredit macet Bank Indonesia (OJK, 2016). Adanya syarat-syarat ini diharapkan pembiayaan dengan akad musyarakah dapat dilaksanakan tanpa menyebabkan tingginya pembiayaan bermasalah.

Dengan demikian penyaluran pembiayaan dengan prinsip bagi hasil tidak akan berdampak pada pembiayaan bermasalah, jika syarat-syarat standar yang ditentukan oleh Otoritas Jasa Keuangan dapat dipenuhi. Secara konsep pembiayaan dengan prinsip bagi hasil memang memiliki risiko yang tinggi (Putra, 2019; (Warninda et al., 2019; Aprilianto, 2020). Oleh karena tingginya risiko dalam pembiayaan dengan prinsip bagi hasil, menjadi salah satu penyebab rendahnya jumlah penyaluran pembiayaan dengan prinsip bagi hasil (Afzal \& Hassan, 2018).

Risiko pembiayaan dalam perbankan dapat dinilai dari tinggi rendahnya Non performing financing yang selanjutnya disingkat NPF (Koju et al., 2018). NPF merupakan suatu kondisi dimana nasabah tidak sanggup untuk membayar seluruh atau sebagaian kewajibannya kepada bank sebagaimaa yang telah ditentukan dalam akad. Pembiayaan bermasalah secara umum dapat digolongkan kurang lancar, diragukan dan macet(Sa'diyah, 2019). NPF menunjukkan besar kecilnya pembiayaan macet di lembaga pemberi pembiayaan (Suardi, Siregar, \& Hakim, 2016). Dengan demikian NPF yang tinggi menandakan suatu lembaga akan kehilangan keuntungan dan kemungkinan besar asetnya. Dengan demikian NPF akan berdampak buruk bagi lembaga keuangan, karena dapat menyebabkan berkurangannya keuntungan dan juga aset (Sudarsan \& Santosh, 2019).. Suatu pembiayaan dikatakan bermasalah jika pembayaran pokok dan jasa tidak dapat dilakukan pada saat jatuh tempo dan tidak lagi diantisipasi di masa yang akan datang (Koju et al., 2018). Sehingga lembaga keuangan tidak memiliki kesempatan untuk mendapatkan keuangan (Asfaw et al., 2016). NPF dapat terjadi jika (1) pembayaran pokok dan bunga tidak dibayarkan dan tidak dapat dicegah, (2) Pokok pembiayaan tidak dibayarkan lebih dari 90 hari dan (3) pembayaran tidak dilakukan padahal sudah jatuh tempo (Msigwa, 2013).

Pembiayaa bermasalah atau kredit macet menurut Msigwa (2013) dapat disebabkan oleh kesengajaan dari nasabah dan pemberian informasi yang tidak benar. Dengan demikian untuk mencegah adanya pembiayaan bermasalah yang merugikan, Otoritas Jasa Keuangan menentukan persyaratan standar dalam pembiayaan dengan prinsip bagi hasil. Standar-standar yang telah disusun harus dipenuhi oleh bank syariah dalam penyaluran pembiayaan. Dengan demikian penyaluran pembiayaan akan berdampak pada pengurangan NPF jika dalam proses pembiayaan dilakukan dengan menerapkan standar yang ditentukan oleh Otoritas Jasa Keuangan. Studi yang dilakukan oleh Putri et al (2018) membuktikan bahwa berbasis bagi hasil dengan akad mudharabah berpengaruh negatif terhadap pembiayaan bermasalah. Demikian halnya studi yang dilakukan oleh Adzimatinur \& Manalu (2020) membuktikan bahwa pembiayaan bagi hasil dengan akad musyarakah memiliki pengaruh negatif dan signifikan terhadap pembiayaan bermasalah. Dari uraian ini maka hipotesis yang diajukan pada studi ini adalah

H1: Pembiayaan dengan akad Mudharabah berdampak negatif terhadap pembiayaan bermasalah.

H2: Pembiayaan dengan akad Musyarakah berdampak negatif terhadap pembiayaan bermasalah.

\section{METODE PENELITIAN}

Jenis penelitian ini adalah penelitian eksplanatori yaitu penelitian yang bertujuan untuk melakukan pengujian adanya pengaruh antara variabel independen terhadap variabel dependen (Yin, 2008). Variabel dependen pada studi ini adalah risiko pembiayaan yang diukur dengan NPF 
dalam bentuk (persentase). Adapun variabel independen pada studi terdiri dari dua variabel yaitu pembiayaan dengan akad mudharabah dan pembiayaan dengan akad musyarakah. Akad mudharabah diukur dengan jumlah pembiayaan yang disalurkan oleh bank umum syariah dengan akad mudharabah dalam bentuk rupiah. Demikian halnya dengan variabel pembiayaan dengan akad musyarakah yang juga diukur dengan jumlah pembiayaan yang disalurkan oleh bank umum syariah dalam bentuk rupiah.

Jenis penelitian eksplanatori ini sesuai dengan tujuan penelitian ini yaitu untuk menguji ada tidaknya pengaruh antara pembiayaan bagi hasil (mudharabah dan musyarakah) dengan risiko pembiayaan yang dalam studi ini diukur dengan NPF. Sumber data pada penelitian ini berasal dari laporan dari bank umum syariah di Indonesia yang terdiri dari 14 bank umum syariah yaitu (Bank Muamalat Indonesia, Bank Victoria Syariah, BRISyariah, BNI Syariah, Bank Syariah Mandiri, Bank Syariah Mega Indonesia, Bank Panin Dubai Syariah, Bank Syariah Bukopin, BCA Syariah, Bank Net Indonesia Syariah, Bank Tabungan Pensiunan Nasional Syariah) dan 3 bank daerah (Bank Jabar Banten Syariah, Bank Aceh Syariah, Bank NTB Syariah). Dari 14 bank umum syariah di Indonesia setelah dilakukan sampling hanya hannya ada 9 bank umum syariah yang memenuhui kriteria untuk di jadikan sampel yaitu BCA Syariah, BNI Syariah, BRI Syariah, BJB Syariah, Bank Muamalat Indonesia, Bank Panin Dubai Syariah, Bank Syariah Bukopin, Bank Syariah Mandiri, Bank Victoria Syariah.

Setelah sampling ditentukan kemudian dilakukan pengumpulan data. Pengumpulan data dilakukan dengan menggunakan dokumentasi (laporan keungan masing-masing bank yang menjadi sampel penelitian). Data penelitian diperoleh melalui laporan yang diupload di situs resmi dari bank umum syariah yang menjadi sampel penelitian. Melalui situs resmi tersebut maka peneliti mendapatkan data-data yang diperlukan dalam analisis data.

Setelah data-data yang dibutuhkan dalam analisis data berhasil dikumpulkan, tahap selanjutnya adalah melakukan analisis data. Analisis data pada studi ini menggunakan analisis regresi data panel. Dalam analisis regresi data panel ada tiga teknik yang dapat digunakan yaitu common effect. fixed effect dan random effect (Widarjono, 2013). Oleh karena model menawarkan tiga alternative model studi, maka diperlukan pengujian kesesuaian model. Pertama adalah melakukan uji Chow yang dilakukan untuk memilih manakah model terbaik diantara pooled least square atau fixed effect. Kedua uji Langrange Multiplier atau biasa dikenal dengan uji LM test, uji dilakukan untuk memilih manakah model terbaik diantara Pooled Least Square atau random effect. Ketiga Uji Hausman yang dilakukan untuk memilih model terbaik diantara fixed effect model atau random effect model (Widarjono, 2013).

\section{HASIL DAN PEMBAHASAN}

\section{Statistik Deskriptif}

Statistik deskriptif perlu disajikan untuk memudahkan dalam membaca data-data yang dikumpulkan ke dalam data statistik. Statistik deskriptif pada studi ini adalah terdiri dari maximum, minimum, mean (rata-rata) dan standar deviasi. Analisis deskriptif yang diperoleh adalah sebagai berikut:

Tabel 2: Statistik Deskriptif

\begin{tabular}{lcccc}
\hline \multicolumn{1}{c}{ Variabel } & Mean & Maximum & Minimum & Std. Deviasi \\
\hline Mudarabah & 836.033 & 3.597 .104 & 223.543 & 980061,9 \\
\hline Musyarakah & 6.189 .402 & 21.449 .077 & 784.074 & 6597722 \\
\hline NPF & 5,680926 & 22,29 & 0,32 & 4.934677 \\
\hline
\end{tabular}

Sumber: Output Eviews 9 (2020)

Dari data pada tabel 2 di atas, dapat diketahui bahwa nilai rata-rata (mean) dari mudarabah adalah 836033 dengan standar deviasi 980061,9 pada pembiayaan musyarakah nilai rata-ratanya adalah 6189402 Dengan standar deviasi 6597722 dari 108 sample data triwulan Maret 2016- 
Desember 2018. Pembiayaan mudarabah dengan maximum 3.597.104 yaitu pada Bank Mandiri Syariah dan minimum 223.543 pada Bank Jabar Banten Syariah. Pada pembiayaan Musyarakah nilai maximum adalah 21.449.077 yaitu pada Bank Syariah Mandiri dan nilai minimum 784.074 pada Bank Jabar Banten Syariah. Sesuai dengan tabel di atas, variabel NPF menunjukkan nilai maximum 22,29 dan nilai minimum 0,32 dengan nilai rata-rata 5,68 dan standar deviasi sebesar 4.93.

\section{Uji Kesesuaian Model}

Sebagaimana telah dijelaskan dalam metode, studi ini menggunakan analisis regresi data panel, sehingga diperlukan uji kesesuaian model. Hasil dari uji kesesuian model adalah sebagai berikut:

Tabel 3: Uji Kesesuaian Model

\begin{tabular}{ccccc}
\hline Variabel Y & Uji Model & Hasil & Hipotesis & Kesimpulan \\
\hline \multirow{2}{*}{$\begin{array}{c}\text { Non } \\
\text { Performing } \\
\text { Finance }\end{array}$} & $\begin{array}{c}\text { Chow Test (common effect or fixed } \\
\text { effect) }\end{array}$ & 0.0000 & Menolak H0 & Fixed Effect \\
\cline { 2 - 5 } & $\begin{array}{c}\text { Hansman Test (fixed effect or } \\
\text { random effect) }\end{array}$ & 0.2350 & $\begin{array}{c}\text { Gagal } \\
\text { Menolak H0 }\end{array}$ & Random Effect \\
\cline { 2 - 5 } & random effect) & 0.0000 & Menolak H0 & Random Effect \\
\hline
\end{tabular}

Dari tabel 3 di atas dapat dirakit kesimpulan bahwa model yang sesuai dengan studi ini adalah model random effect. Kesimpulan ini diperoleh dari hasil uji chow test, hausman test, dan Langrange Multiplier. Dari uji chow diperoleh model terbaik dalam studi ini adalah fixed effect. Sementara dalam uji hausman test hasilnya adalah model random effect. Maka dilanjutkan dengan uji LM untuk menentukan model terbaiknya, dan diperoleh hasil random effect, dapat disimpulkan bahwa random effect adalah model terbaiknya.

\section{Estimasi Regresi}

Hasil uji kesesuaian model menujukkan bahwa model regresi data panel yang terbaik pada studi ini adalah menggunakan random effect. Hasil estimasi regresi dengan menggunakan random random effect adalah sebagai berikut:

Tabel 4: Hasil Regresi Data Panel Pendekatan Random Effect

\begin{tabular}{|c|c|c|c|c|}
\hline Variabel & Coefficient & Std. Error & $\mathrm{t}$-Statistic & Prob. \\
\hline $\mathrm{C}$ & 71.49636 & 25.86065 & 2.764678 & 0.0067 \\
\hline LNX1 (Mudharabah) & -2.289968 & 0.454224 & -5.041498 & 0.0000 \\
\hline LNX2 (Musyarakah) & -0.157255 & 0.881505 & -0.178394 & 0.8588 \\
\hline \multicolumn{5}{|c|}{ Weighted Statistics } \\
\hline R-squared & 0.203178 & \multicolumn{2}{|c|}{ Mean dependent var } & 0.868847 \\
\hline Adjusted R-squared & 0.188001 & \multicolumn{2}{|c|}{ S.D. dependent var } & 2.681219 \\
\hline S.E. of regression & 2.416073 & \multicolumn{2}{|c|}{ Sum squared resid } & 612.9282 \\
\hline F-statistic & 13.38677 & \multicolumn{2}{|c|}{ Durbin-Watson stat } & 1.814473 \\
\hline Prob(F-statistic) & 0.000007 & & & \\
\hline \multicolumn{5}{|c|}{ Unweighted Statistics } \\
\hline R-squared & -0.019598 & \multicolumn{2}{|c|}{ Mean dependent var } & 5.680926 \\
\hline Sum squared resid & 2656.624 & \multicolumn{2}{|c|}{ Durbin-Watson stat } & 0.257128 \\
\hline
\end{tabular}

Sumber: Hasil Eviews 9 (2020)

Hasil estimasi regresi dengan pendekatan random effect di atas menunjukkan pengaruh variabel independen (mudharabah dan musyarakah) terhadap variabel dependen (Y). Adapun arti dari koefisien regresi tersebut adalah sebagai berikut: 
a. Konstanta $(\alpha)$ sebesar 71.49636

Artinya variabel mudarabah dan musyarakah tidak ada atau nol maka NPF sebesar 71.49636.

b. Koefisien Mudharabah (LNX1) sebesar -2.289968

Artinya jika variabel mudharabah mengalami peningkatan pada bank umum syariah periode Maret 2016-Desember 2018 maka NPF mengalami penurunan sebesar -2.289968.

c. Koefisien LNX2 (Musyarakah) sebesar -0.157255

Artinya jika variabel musyarakah mengalami peningkatan maka NPF mengalami penurunan sebesar -0.157255 .

\section{Pembahasan}

\section{Pembiayaan Mudarabah Terhadap Non Performing Finance (NPF)}

Hasil dari uji regresi dengan pendekatan random effect menunjukkan bahwa pembiayaan mudharabah berpengaruh signifikan negatif terhadap NPF. Hasil ini menunjukkan bahwa semakin tinggi pembiayaan dengan akad mudharabah, maka NPF akan semakin berkurang. Studi ini mendukung hasil studi yang dilakukan oleh Putri et al (2018) bahwa pembiayaan dengan akad mudharabah memiliki pengaruh negatif signifikan terhadap NPF. Kondisi ini dapat dijelaskan bahwa tingginya risiko dalam pembiayaan mudharabah membuat perbankan syariah melakukan seleksi yang ketat. Seleksi yang ketat disatu sisi menjadi penghambat dalam penyaluran pembiayaan mudharabah namun disatu sisi dapat mengurangi pembiayaan bermasalah.

Orotritas Jasa Keuangan telah mengatur mengenai persyaratan standar bagi bank syariah dalam menyalurkan pembiayaan dengan akad mudharabah. Syarat standar tersebut seperti minimal usaha telah berjalan 2 tahun untuk nasabah Walk in Client. Bagi nasabah yang mendapatkan rekomendasi dari nasabah eksisting serta memiliki manajemen yang baik dapat memperoleh pembiayaan mudharabah apabila telah menjalankan usahanya minimal 1 tahu. Syarat standar selanjutnya adalah nasabah memiliki kolektibilitas minimum lancar selama 6 bulan berturut-turut (OJK, 2017).

Dari uraian di atas menunjukkan bahwa peningkatkan pembiayaan mudharabah pada bank umum syariah ternyata menyebabkan penurunan NPF. Penurunan ini salah satunya adalah tingkat kepatuhan bank umum syariah untuk menerapkan persyaratan standar yang telah ditetapkan oleh Otoritas Jasa Keuangan. Persyaratan standar yang ditentukan Otoritas Jasa Keuangan pada dasarnya untuk mencegah timbulnya pembiayaan bermasalah dalam penyaluran dana menggunakan akad mudharabah. Ketika persyaratan standar dapat dipenuhi maka risiko pembiayaan bermasalah dapat dimininamilisir.

\section{Pembiayaan Musyarakah Terhadap Non Performing Financing (NPF)}

Hasil dari uji regresi dengan pendekatan random effect menunjukkan bahwa pembiayaan yang disalurkan oleh bank umum syariah dengan akad musyarakah memiliki pengaruh negatif, namun tidak signifikan secara statistik. Hasil studi ini tentunya tidak sejalan dengan anggapan bahwa pembiayaan dengan akad musyarakah memiliki risiko, karena berpengaruh positif terhadap pembiayaan bermasalah (Aprilianto, 2020). Kendati secara statistik pembiayaan musyarakah tidak signifikan, namun koefisien yang dihasilkan adalah negatif. Artinya pembiayaan musyarakah memiliki potensi untuk menurunkan NPF. Berbeda dengan akad mudharabah dimana bank umum tidak dapat terlibat dalam pelaksanaan usaha nasabah, namun pada akad musyarakah bak syariah dapat terlibat dalam proses usaha. Dengan demikian proses risiko terjadinya kegagalan usaha dapat dicegah sejak awal.

Sama halnya penyaluran pembiayaan dengan akad mudharabah, Otoritas Jasa Keuangan juga telah membuat standar dalam penyaluran pembiayaan dengan musyarakah. Nasabah dapat memperoleh pembiayaan dengan akad musyarakah jika usaha yang dijalankan oleh Perusahaan/Badan Usaha telah memenuhi syarat terkait dokumen perijinan yang diperlukan seperti Akta Perusahaan yang telah disahkan oleh Institusi Berwenang, Nomor Pokok Wajib Pajak serta kelengkapan dokumen-dokumen perijinan usaha dari Institusi Berwenang. Syarat 
standar lainnya adalah nasabah perorangan maupun Perusahaan/Badan Usaha tidak tercantum dalam daftar hitam dan daftar kredit macet Bank Indonesia (OJK, 2016). Adanya syarat-syarat ini diharapkan pembiayaan dengan akad musyarakah dapat dilaksanakan tanpa menyebabkan tingginya pembiayaan bermasalah.

Hasil studi ini setidaknya menepis anggapan bahwa pembiayaan berdampak positif terhadap pembiayaan bermasalah, sebagaimana hasil studi yang dilakukan oleh Aprilianto (2020) bahwa pembiayaan bagi hasil berdampak positif terhadap pembiayaan bermasalah. Hasil studi ini setidaknya mendukung studi yang dilakukan oleh Adzimatinur \& Manalu (2020) membuktikan bahwa pembiayaan bagi hasil dengan akad musyarakah memiliki pengaruh negatif dan signifikan terhadap pembiayaan bermasalah.

\section{PENUTUP}

Berdasarkan hasil studi yang telah dilakukan maka kesimpulan yang dapat diambil dalam studi ini adalah pembiayaan bagi hasil memiliki pengaruh negatif terhadap risiko pembiayaan pada bank syariah di Indonesia. Hasil ini menunjukakan bahwa peningkatan pembiayaan dengan prinsip bagi hasil (mudharabah dan musyarakah) dapat mengurangi non performing financing (NPF).

Dari hasil studi ini maka penting bank pelaku perbankan syariah untuk mengambil kebijakan yang tepat mengenai penyaluran pembiayaan dengan prinsip bagi hasil (mudharabah dan musyarakah). Karena pada dasarnya adalah pembiayaan yang memiliki risiko yang tinggi, namun apabila bank umum syaraiah mematuhi persyaratan standar yang ditetapkan oleh Otoritas Jasa Keuangan maka risiko pembiayaan bermasalah dapat dicegah. Dengan demikian pembiayaan dengan prinsip bagi hasil (mudharabah dan musyarakah) dapat diimplementasikan apabila dibarengi dengan kebijakan yang tepat.

\section{DAFTAR PUSTAKA}

Abraham, R., \& Harrington, C. 2013. Measuring Profit in Cooperatives: Definition and Methods. International of Business, Humanities and Technology, Vol. 3. No. 4.

Ascarya, \& Yumanita, D. 2005. Bank Syariah: Gambaran Umum. Jakarta: PPSK.

Adzimatinur, F., \& Manalu, V. G. 2020. The Impact of Mudharabah and Musharakah based Financing to Credit Risk. In 1st Annual Conference of Ibtifaz: Islamic Economics, Finance, and Banking (pp. 127134). Yogyakarta: Universitas Ahmad Dablan Yogyakarta.

Afzal, T., \& Hassan, S. 2018. Hindrance of Mudharabah Financing: A Study from Islamic Banking Industry of Pakistan. International Journal of Islamic Banking and Finance Research, Vol. 2 No. 2

Ahmadiono. 2013. Dasar-Dasar Bank Syari'ah. Jember: ST AIN Jember Press.

Al-Hasani, F. 2017. Akad Mudharabah Mutlaqah dalam Praktik Perbankan Syariah. Muamalat: Jurnal Hukum Ekonomi Syariah, Vol. 9 No. 2

Antonio, M. S. 2009. Bank Syariah Dari Teori Ke Praktek. Jakarta: Gema Insani Press.

Aprilianto, F. 2020. An Analysis of Financing Scheme Effect on Non-Performing Financing Asset at Islamic Banks In Indonesia. Falab: Jurnal Ekonomi Syariah, Vol. 5 No. 1

Asfaw, A. S., Bogale, H. N., \& Teame, T. T. 2016. Factors Affecting Non-Performing Loans : Case Study on Development Bank of Ethiopia Central Region. International Journal of Scientific and Research Publications, Vol. 6 No. 5 
Belkhaoui, S., Alsagr, N., \& van Hemmen, S. F. 2020. Financing modes, risk, efficiency and profitability in Islamic banks: Modeling for the GCC countries. Cogent Economics and Finance, Vol. 8. No. 1

Ernawati. 2016. Risk of Profit Loss Sharing Financing: the Case of Indonesia. Al-Iqtishad: Journal of Islamic Economics, Vol. 8 No. 1

Hadi, A. C. 2011. Problematika Pembiayaan Mudharabah di Perbankan Syariah Indonesia. Al-Iqtishad, Vol. 3 No. 2

Husa, P. P., \& Trinarningsih, W. 2015. Credit Risk in Indonesia: Islamic Bank vs Conventional Bank Putri. Fokus Manajerial, Vol. 13 No. 1

Karim, A. A. 2010. Bank Islam Analisis Fiqih dan Kenangan. Jakarta: Raja Grafindo Persada.

Koju, L., Koju, R., \& Wang, S. 2018. Macroeconomic and Bank-Specific Determinants of Non-Performing Loans : Evidence from Nepalese Banking System. Journal of Central Banking Theory and Practice, Vol. 71 No. 3

Msigwa, C. 2013. Factors affecting non-performing loans in banking industry : a case of kecb bank (Tanzania) Limited; Morogoro and Msimbazi Branches. Mzumbe University.

OJK. 2019a. Snapshot Perbankan Syariah Indonesia 2019. Jakarta: Otoritas Jasa Kenangan.

OJK. 2019b. Statistik Perbankan Syariah Desember 2019. Otoritas Jasa Kenangan. Jaka: Otoritas Jasa Keuangan.

OJK. 2020. Statistik Perbankan Syariah. Otoritas Jasa Kenangan Syariah. Jakarta: Otoritas Jasa Kenangan.

OJK. 2016. Standar Produk Perbankan Syariah (Musyarakah dan Musyarakah Mutanaqishah. Jakarta: Otoritas Jasa Keuangan.

OJK. 2017. Standar Produk Mudharabah. Jakarta: Otoritas Jasa Kenangan.

Purwanto. 2018. Kontribusi Pembiayaan Sektor Pertanian Bank Syariah Terbadap Kesejabteraan Petani di Pulau Sumatera Periode 2016-2017. Share: Jurnal Ekonomi Kenangan Islam, Vol. 7 No. 1

Purwanto. 2019a. Meningkatkan Profitabilitas dengan Menerapkan Islamic Corporate Identity (Studi Pada Bank Umum Syariah di Indonesia tahun 2014-2017). Jurnal Ekonomi \& Perbankan Syariah, Vol. 6 No. 2

Purwanto. 2019b. Profitabilitas Bank Syariah Ditinjau dari Pembiayaan dengan Prinsip Bagi Hasil dan Kategori Usaha. Cakrawala: Jurnal Studi Islam, Vol. 14 No. 1

Purwanto dan Yanuar, F. 2017. Kontribusi Pembiayaan yang Diberikan oleh Perbankan Syariah Terbadap Produk Domestik. Regional Bruto di Pulau Jawa Dan Sumatera Tahun 2012-2016. Iqtishadia, Vol. 4 No. 2

Putra, R. N. A. 2019. Karakteristik Pembiayaan dan Non Performing Finance Perbankan Syariab 20152018. Malia: Journal of Islamic Banking and Finance, Vol. 3 No. 1

Putri, A. T., Yuliana, S., \& Yulianita, A. 2018. Dana pihak ketiga, Inflasi dan Pembiayaan Mudharabah terhadap Non Performing Financing pada Bank. Islam di Indonesia dan Malaysia. Jurnal Ekonomi Pembangunan, Vol 16 No. 2 
Sa'diyah, M. 2019. Strategi Penanganan Non Performing Finance (NPF) Pada Pembiayaan Murabahah di BMT. Conference on Islamic Management Accounting and Economics (CIMAE) Proceding, Vol. 2

Sa'diyah, M., \& Aziroh, N. 2014. Musyarakah dalam Fiqh dan Perbankan Syariah. Equilibrium, Vol. 2 No. 2

Santoso, M. H. E., \& Nurzaman, M. S. 2020. Asesmen Kontribusi Kenangan Syariah Terbadap Pertumbuhan Ekonomi di Indonesia. Al-Mashrafiyah: Jurnal Ekonomi, Keuangan Dan Perbankan Syariah, Vol 4 No. 1

Suardi, I., Siregar, H., \& Hakim, D. B. 2016. Analysis Of Factors Affecting The Non Performing Loans ( NPL) Of Microcredit And Its Impact On Credit Channeling In Microfinance Sector In Regional Office X of PT Bank XYZ. International Journal of Development Research, Vol. 6 No. 11

Sudarsan, K., \& Santosh, K. 2019. Nexus Between Non-Performing Assets And Macroeconomic Variables - A Study Of Indian Banking Sector. International Journal Of Scientific \& Technology Research, Vol. 8 No. 11

Sutrisno. 2015. Perbankan Syariab: Antara Idealisme dan Oportunisme (Studi Kasus Pada Perbankan Syariah di Indonesia). Jurnal Kenangan dan Perbankan, Vol. 19 No. 3.

Sutrisno. 2016. The Effect Of Funding And Risk On Financing Decision Empirical Study of Islamic Banks in Indonesia. Inferensi: Jurnal Penelitin Sosial Keagamaan, Vol. 10 No. 1

Wangsawidjaja. 2012. Pembiayaan Bank Syariah. Jakarta: Gramedia Pustaka Utama.

Warninda, T. D., Ekaputra, I. A., \& Rokhim, R. 2019. Do Mudarabah and Musharakah financing impact Islamic Bank credit risk differently? Research in International Business and Finance, Vol. 49 No. 2

Widarjono, A. 2013. Ekonometrika Pengantar dan Aplikasinya disertai Panduan Eviews. Yogyakarta: UPP $A M P Y K P N$.

Yin, Robert. 2008. Studi Kasus (Desain dan Metode), (Case Study Research Design and Methods") diterjemabkan oleh Djauzi Mudzakir. Jakarta: PT.Raja Grafindo Persada 